\section{Heading Fruiting Shoots before Bloom Is Equally Effective as Blossom Removal in Peach Crop Load Management}

\author{
Richard P. Marini \\ Department of Horticulture, Virginia Polytechnic Institute and State University, \\ Blacksburg, VA 24061-0327 \\ Additional index words. Prunus persica, pruning, fruit size, crop load
}

\begin{abstract}
Three experiments were performed to determine if pruning treatments could reduce the need for peach [Prunus persica $\left(L_{\text {. }}\right)$ Batsch] fruit thinning without reducing average fruit weight. To determine if dormant shoot heading affected fruit size simply by reducing the number of flowers per tree, all 1-year-old shoots on 'Cresthaven' trees were headed by $50 \%$ or blossoms were removed from the terminal half of each shoot. At 45 days after full bloom, all trees were hand-thinned to obtain predetermined crop densities. Average fruit weight was highest on trees with blossom removal, but crop value and net profit were highest for nontreated trees. To determine the influence of treatment severity on fruit weight, all shoots on 'Cresthaven' trees were blossom-thinned or headed to remove blossoms on varying proportions of each shoot. Fruit set and the number of fruit removed during postbloom thinning decreased as the percentage of a shoot that was headed or blossom-thinned increased. Average fruit weight at harvest and crop value were higher for trees with blossom removal than for trees with headed shoots. Fruit weight and crop value were not affected by the percentage of the shoot treated. In the final experiment, all shoots on 'Cresthaven' trees were headed by $50 \%$ or were not headed. Heading of shoots reduced fruit set, number of fruits removed at thinning, and thinning time per tree, but yield, crop density, and average fruit weight were not affected by heading. Profit was increased by shoot heading one of the 3 years. Results from this study indicate that heading peach shoots by $50 \%$ while dormant pruning can reduce thinning costs without reducing fruit size, but a similar level of labor-intensive blossom removal may reduce postbloom thinning costs and improve fruit size.
\end{abstract}

Peach trees are pruned to maintain tree shape and size and to partially adjust crop load (Marini, 1988). Even when properly pruned, peach trees often set more fruit than they can adequately size (Byers et al., 1990). Peach fruit size is negatively related to number of fruit per tree (Johnson and Handley, 1989) and positively related to leaf area per fruit (Overholser and Claypool, 1931; Weinberger and Cullinan, 1932). In the mid-Atlantic region of the United States, fresh fruit $<57 \mathrm{~mm}$ in diameter are not marketable. Removing excess fruit within $50 \mathrm{~d}$ after bloom is a standard commercial practice to produce large fruit that bring premium prices. Although handthinning peach trees is expensive and labor intensive, it is cost effective. Bloom thinning with chemicals is less expensive, but results are inconsistent (Byers and Lyons, 1985). Dragging ropes over trees during bloom to physically remove some blossoms is cost effective but, to obtain satisfactory results, trees must be carefully pruned to an open-center shape (Baugher et al., 1988). Reducing the crop load before or during bloom maximizes fruit size, and hand-thinning becomes less effective for each day after bloom that thinning is delayed (Havis, 1962).

Received for publication 14 June 2001. Accepted for publication 17 Sept. 2001.
Because postbloom hand-thinning of fruit is one of the most labor-intensive and expensive operations in peach production, additional cost-effective methods that are less labor intensive are needed to adjust crop load and improve fruit size. The objective of this study was to determine if heading 1-year-old fruiting shoots before bloom can reduce crop load and improve fruit size and profitability compared to trees with blossom-reduction treatments or trees that were hand-thinned 40 to $50 \mathrm{~d}$ after bloom.

\section{Materials and Methods}

Shoot-heading vs. blossom removal, 1993. In early Mar. 1993, forty-five 6-year-old 'Cresthaven' trees were pruned and all 1-yearold shoots that were $<30 \mathrm{~cm}$ long were removed. During bloom, 15 trees were rancontrol—no crop load adjustment before $45 \mathrm{~d}$ after full bloom (DAFB); 2) shoot headingthe terminal half of all 1-year-old shoots was removed while dormant pruning; and 3) blossom removal-blossoms were removed by hand from the terminal half of all 1-year-old shoots during bloom. For all experiments in this study, shoot-heading and blossom removal were based on visual estimates rather than on precise measurements. Forty-five DAFB five trees per treatment were hand-thinned to a crop density (CD) of 3,6 , or 9 fruit $/ \mathrm{cm}^{2}$ trunk cross-sectional area (TCSA). The experiment domly assigned to each of three treatments: 1 ) was a $3 \times 3$ factorial in a completely randomized design (CRD) with five single-tree replicates. Fruit removed by hand-thinning were counted and weighed. On 17 Aug. all fruit with yellowish-green ground color were harvested, counted, weighed, and graded into four sizes. TCSA was recorded for each tree after leaf drop in November, and was used to calculate $\mathrm{CD}$ and yield efficiency (YE) (kilograms of harvested fruit per square centimeter TCSA). Most of the remaining fruit were yellowishgreen on 21 Aug. when all remaining fruit were harvested. A partial economic analysis was performed for each treatment. In this study, the only factors considered to be affected by treatments included thinning time, harvest and packing costs, and the value of the crop. Crop value was calculated for each tree by assigning the following value for each fruit size: $57-63.5 \mathrm{~mm}$ diameter $=\$ 0.58 / \mathrm{kg}(\$ 10.00 /$ $38-\mathrm{lb}$ box); $64-70 \mathrm{~mm}$ diameter $=\$ 0.70 / \mathrm{kg}$ $(\$ 12.00 /$ box $)$; and $>70-\mathrm{mm}$ diameter $=\$ 0.81 /$ $\mathrm{kg}$ (\$14.00/box). Fruit $<57 \mathrm{~mm}$ were assigned no value. Based on conversations with commercial peach producers in Virginia, combined harvest and packing costs were assumed to be $\$ 0.166 / \mathrm{kg}$ (\$2.00/box) for fruit $<57 \mathrm{~mm}$ in diameter, and $\$ 0.318 / \mathrm{kg}$ (\$5.50/box) for fruit $>57 \mathrm{~mm}$ in diameter. Estimated harvest and packing costs were subtracted from the crop value to obtain net profit per tree. This value is not really a "net profit" because costs other than harvest and packing costs were ignored. Data were analyzed with a two-way analysis of variance (ANOVA) using SAS's GLM Procedure (Littell et al., 1992). The degrees of freedom for main effects and interactions were partitioned for preplanned single degree-of-freedom contrasts.

To determine the effect of treatments on shoot and flower bud development, during Nov. 1993 five 1-year-old limb sections (1992 wood) with current-season shoots (shoots that grew from buds in 1993) intact were removed from each tree. The number and length of current-season lateral shoots, 1-year-old shoots, the most terminal shoot, and the number of flower buds were recorded for each limb section.

Severity of shoot-heading vs. blossom removal, 1995. During Mar. 1995, forty 8-yearold 'Cresthaven' trees were pruned and all 1year-old shoots $<30 \mathrm{~cm}$ long were removed. The experiment was a $2 \times 5$ factorial in a CRD with four single-tree replicates. During bloom 20 trees were assigned to one of the following blossom-reducing treatments: 1) shoot-heading-all 1-year-old shoots on the tree were headed to remove a predetermined portion of each shoot; and 2) blossom removal — all blossoms were removed by hand from a predetermined portion of each shoot. Four trees of each treatment were assigned to one of five blossom-reducing treatment levels. All 1-year-old shoots on a tree were either headed or deblossomed to remove blossoms on $0 \%, 50 \%$, $75 \%, 87.5 \%$, or $93.25 \%$ of each shoot so that only the basal portion of each shoot had blossoms. For example, if a 48-cm-long shoot was on a tree that was shoot-headed by $75 \%$, the terminal $36 \mathrm{~cm}$ were removed by heading and 
a 12-cm-long headed shoot with blossoms remained. If a similar shoot was on a blossomremoval tree, blossoms were removed from the terminal $36 \mathrm{~cm}$ of the shoot and the $48-\mathrm{cm}$ long shoot had blossoms only on the basal 12 $\mathrm{cm}$. At 40 DAFB, trees were hand-thinned to a CD of $\approx 4.0$ fruit $/ \mathrm{cm}^{2}$ TCSA. Fruit removed by thinning were counted and weighed. On three dates in mid-August, fruit with yellowish-green ground color were harvested, counted, weighed, and graded into four sizes. Crop value and net profit were calculated as described previously. Data were analyzed with a two-way ANOVA. The degrees of freedom were partitioned for preplanned single degreeof-freedom contrasts.

Shoot-heading, 1996. Before bloom in 1996, forty 9-year-old 'Cresthaven' trees were selected for uniformity. TCSA was calculated and during dormant pruning all short shoots ( $<30 \mathrm{~cm}$ long) were removed. Twenty trees were assigned randomly to each of two treatments (nonheaded shoots vs. shoots headed by $50 \%$ ). Four trees per treatment were pruned to retain enough 1-year-old shoots to produce CDs of $4,5,6,7$, or 8 fruit $/ \mathrm{cm}^{2}$ TCSA when only two fruit/shoot were retained after handthinning at 40 DAFB. The time required to head shoots and hand-thin fruit were recorded for each tree. Excess fruit removed during hand-thinning were counted and weighed. Trees were harvested on the basis of ground color three times in mid-August. At harvest, fruit were counted, weighed, and graded into four sizes with a weight sizer. Crop value was calculated as previously described. Net profit was calculated as the crop value minus costs for shoot heading and blossom removal (\$6.00/ h) plus harvest and packing costs. The factorial experiment had two treatments and five levels of CD in a CRD. Data were analyzed as a two-way ANOVA, and degrees of freedom were partitioned for preplanned single degreeof-freedom contrasts.

\section{Results}

Shoot-heading vs. blossom removal, 1993. Means and $P$ values for main effects and the treatment $\times \mathrm{CD}$ interaction for all response variables are presented in Table 1 . To explore these interactions, regression analysis was used to evaluate the linear relationship between each response variable and $\mathrm{CD}$ for each treatment.

When counted at 45 DAFB, the number of fruit set per tree ranged from 425 to 2100 (data not shown). More fruit set on control trees than on the average of trees with blossom-removed and headed shoots (Table 1). More fruit were removed during postbloom thinning for control trees than for the average of trees with bloom-thinned and headed shoots. Fruit set, and weight of thinned fruit did not differ for trees with headed or blossom-thinned shoots. The number of fruit removed during postbloom thinning was highest for the control trees and lowest for the blossom-removal trees. A lower percentage of fruit was removed from blossom-thinned trees than from control trees or trees with headed shoots. Average fruit weight of thinned fruit was not influenced by the thinning-method treatments, but average fruit weight was negatively related to CD. Small or blemished fruit were preferentially removed during thinning, so the reason that average FW of thinned fruit at harvest was negatively related to $\mathrm{CD}$ was probably because removal of more relatively large fruit was required to obtain the desired CD on trees with the lowest CD.

The single degree-of-freedom contrasts indicated that the number and weight of fruit harvested per tree were highest for control trees and lowest for trees with headed shoots. For all treatments, number and total weight of harvested fruit per tree increased linearly with increasing $\mathrm{CD}$. Average fruit weight harvest was not affected by treatment, but declined linearly as CD increased for all treatments except the control. The CD and YE were highest for control trees and lowest for trees with headed shoots. Crop value and net profit were higher for control trees than for the average of blossom-removal and shoot-headed trees. Crop value and net profit were also higher for blossom-removed trees than for shoot-headed trees. Crop value and net profit were linearly and positively related to CD for all treatments.

Response variables for vegetative growth were not affected by $\mathrm{CD}$ and the blossomreducing treatment $\times \mathrm{CD}$ interaction was nonsignificant, so means for the main effect of blossom-reducing treatment are presented in Table 2. Vegetative growth was generally similar for control trees and trees with blossom-thinned shoots. The average length of 1year-old shoots (1992 growth) on trees with headed shoots was half that of blossom-thinned trees because all shoots were headed by $50 \%$. Shoot-heading reduced the number of current-

Table 1. Influence of blossom removal (BR), shoot heading (SH), and crop density (fruit/ $\mathrm{cm}^{2} \mathrm{TCSA}$ ) (CD) on number of fruit set per tree (set), number of fruit thinned per tree thinned or harvested per tree (no.), weight of fruit removed by thinning ( $\mathrm{kg} / \mathrm{tree})(\mathrm{wt})$, percentage of fruit set removed at thinning (\% thin), average fruit weight $(\mathrm{FW})$ at thinning and harvest $(\mathrm{g})$, yield $\left(\mathrm{kg} /\right.$ tree), yield efficiency $\left(\mathrm{kg}\right.$ fruit $\left.\cdot \mathrm{cm}^{-2} \mathrm{TCSA}\right)(\mathrm{YE})$, crop value ( $\$$ tree), and net profit ( $\$ /$ tree) of 'Cresthaven' peach trees in 1993 .

\begin{tabular}{|c|c|c|c|c|c|c|c|c|c|c|c|c|c|}
\hline \multirow[b]{2}{*}{ Treatment $^{\mathrm{x}}$} & \multirow[b]{2}{*}{$\begin{array}{c}\mathrm{CD} \\
\text { (fruit } / \mathrm{cm}^{2} \text { ) }\end{array}$} & \multirow[b]{2}{*}{$\begin{array}{c}\text { Set } \\
\text { (no./tree) }\end{array}$} & \multicolumn{4}{|c|}{ Fruit removed at thinning time ${ }^{z}$} & \multicolumn{7}{|c|}{ Harvested fruit } \\
\hline & & & $\begin{array}{l}\text { Thinning } \\
\text { (no./tree) }\end{array}$ & $\begin{array}{c}\mathrm{Wt} \\
(\mathrm{kg} / \mathrm{tree})\end{array}$ & $\begin{array}{l}\text { Thin } \\
(\%)\end{array}$ & $\begin{array}{l}\text { FW } \\
(\mathrm{g})\end{array}$ & (No./tree) & $\begin{array}{c}\text { Yield } \\
\text { (kg/tree) }\end{array}$ & $\begin{array}{l}\text { FW } \\
(\mathrm{g})\end{array}$ & $\begin{array}{c}\mathrm{CD} \\
\text { (fruit/cm²) }\end{array}$ & $\begin{array}{c}\mathrm{YE} \\
\left(\mathrm{kg} \cdot \mathrm{cm}^{-2}\right)\end{array}$ & $\begin{array}{l}\text { Value } \\
\text { (\$/tree) }\end{array}$ & $\begin{array}{c}\text { Net }^{\mathrm{y}} \\
(\$ / \text { tree })\end{array}$ \\
\hline Control & & 1359 & 955 & 11.9 & 68 & 12.9 & 403 & 53.2 & 134 & 6.8 & 0.90 & 39.8 & 23.7 \\
\hline $\mathrm{BR}$ & & 1037 & 669 & 9.7 & 58 & 13.5 & 368 & 50.4 & 141 & 6.4 & 0.87 & 38.0 & 22.8 \\
\hline \multirow[t]{4}{*}{$\mathrm{SH}$} & & 1162 & 809 & 9.8 & 68 & 12.6 & 354 & 47.3 & 138 & 5.6 & 0.75 & 34.8 & 20.7 \\
\hline & 3 & 1224 & 977 & 14.0 & 79 & 14.4 & 247 & 36.7 & 147 & 3.9 & 0.58 & 29.2 & 17.9 \\
\hline & 6 & 1246 & 898 & 11.4 & 71 & 12.9 & 348 & 48.9 & 142 & 5.7 & 0.81 & 37.7 & 22.8 \\
\hline & 9 & 1087 & 558 & 5.9 & 44 & 11.6 & 529 & 65.5 & 124 & 9.2 & 1.13 & 45.6 & 26.6 \\
\hline \multirow[t]{3}{*}{ Control } & 3 & 1323 & 1088 & 14.1 & 82 & 13.1 & 234 & 32.9 & 140 & 4.0 & 0.57 & 26.0 & 15.8 \\
\hline & 6 & 1300 & 887 & 12.9 & 67 & 14.4 & 413 & 56.5 & 137 & 6.5 & 0.89 & 42.8 & 25.8 \\
\hline & 9 & 1452 & 889 & 8.6 & 55 & 11.2 & 563 & 70.3 & 125 & 9.8 & 1.23 & 50.42 & 29.6 \\
\hline \multirow[t]{3}{*}{ BR } & 3 & 1356 & 1090 & 16.2 & 81 & 14.5 & 266 & 40.8 & 152 & 4.1 & 0.62 & 33.3 & 20.5 \\
\hline & 6 & 1042 & 719 & 10.6 & 69 & 14.5 & 322 & 45.9 & 145 & 6.1 & 0.87 & 36.1 & 21.9 \\
\hline & 9 & 713 & 197 & 2.2 & 25 & 11.4 & 516 & 64.5 & 125 & 9.0 & 1.13 & 44.6 & 26.1 \\
\hline \multirow[t]{3}{*}{$\mathrm{SH}$} & 3 & 4995 & 752 & 11.8 & 75 & 15.6 & 242 & 36.2 & 150 & 3.6 & 0.54 & 28.4 & 17.3 \\
\hline & 6 & 1396 & 1086 & 10.8 & 78 & 10.0 & 309 & 44.1 & 144 & 4.6 & 0.66 & 34.2 & 20.7 \\
\hline & 9 & 1098 & 587 & 6.8 & 51 & 12.2 & 509 & 61.6 & 121 & 8.6 & 1.04 & 41.8 & 24.2 \\
\hline \multicolumn{14}{|c|}{$P$ values from ANOVA } \\
\hline \multicolumn{2}{|c|}{ Treatment $(\mathrm{T})$} & 0.062 & 0.052 & 0.336 & 0.013 & 0.623 & 0.453 & 0.579 & 0.343 & 0.008 & 0.009 & 0.525 & 0.527 \\
\hline \multicolumn{2}{|c|}{$\mathrm{CK}$ vs. $\mathrm{BT}+\mathrm{SH}$} & 0.007 & 0.019 & 0.089 & 0.131 & 0.886 & 0.014 & 0.034 & 0.188 & 0.018 & 0.056 & 0.047 & 0.002 \\
\hline \multicolumn{2}{|l|}{ BT vs. SH } & 0.571 & 0.317 & 0.783 & 0.004 & 0.247 & 0.079 & 0.023 & 0.530 & 0.047 & 0.016 & 0.017 & 0.001 \\
\hline \multicolumn{2}{|l|}{$\mathrm{CD}$} & 0.502 & 0.003 & 0.001 & 0.001 & 0.012 & 0.001 & 0.001 & 0.001 & 0.001 & 0.001 & 0.004 & 0.011 \\
\hline \multicolumn{2}{|l|}{$\mathrm{CD}_{\text {Linear }}$} & 0.517 & 0.002 & 0.001 & 0.001 & 0.007 & 0.001 & 0.001 & 0.001 & 0.001 & 0.001 & 0.001 & 0.008 \\
\hline \multicolumn{2}{|l|}{$\mathrm{CD}_{\text {Quad. }}$} & 0.386 & 0.162 & 0.267 & 0.002 & 0.936 & 0.035 & 0.294 & 0.121 & 0.015 & 0.239 & 0.944 & 0.001 \\
\hline \multicolumn{2}{|l|}{$\mathrm{T} \times \mathrm{CD}$} & 0.058 & 0.016 & 0.216 & 0.005 & 0.012 & 0.597 & 0.540 & 0.800 & 0.382 & 0.323 & 0.549 & 0.552 \\
\hline
\end{tabular}

${ }^{\mathrm{z}}$ At 45 DAFB excess fruit were removed to obtain various levels of crop density.

${ }^{y}$ Net profit is the crop value minus harvest and packing costs.

${ }^{x}$ Treatments were: control—no crop load adjustment before $45 \mathrm{~d}$ after full bloom (DAFB); blossom removal—blossoms were removed by hand from the terminal half of all 1-year-old shoots during bloom; shoot heading-the terminal half of all 1-year-old shoots was removed while dormant pruning. 
Table 2. Vegetative growth and flower bud development on 1-year-old shoots (shoots that grew in 1992 and had blossom-removal treatments in Mar. 1993) as influenced by blossom-removal or shoot-heading 'Cresthaven' peach trees measured in Nov. 1993. ${ }^{2}$

\begin{tabular}{lccc}
\hline \hline Response variable & Control & $\begin{array}{c}\text { Blossom } \\
\text { removal }\end{array}$ & Headed \\
\hline Avg length of 1-year-old shoot $(\mathrm{cm})$ & $51 \mathrm{a}^{\mathrm{y}}$ & $52 \mathrm{a}$ & $25 \mathrm{~b}$ \\
No. of current-season lateral shoots/1-year-old shoot & $11 \mathrm{a}$ & $11 \mathrm{a}$ & $4 \mathrm{~b}$ \\
Total length current-season lateral shoots/1-year-old shoot & $72 \mathrm{a}$ & $82 \mathrm{a}$ & $88 \mathrm{a}$ \\
Length of terminal shoot $(\mathrm{cm})$ & $32 \mathrm{~b}$ & $34 \mathrm{~b}$ & $46 \mathrm{a}$ \\
Diam of 1-year-old-shoot $(\mathrm{mm})$ & $8.6 \mathrm{~b}$ & $9.1 \mathrm{a}$ & $8.8 \mathrm{ab}$ \\
Flower buds/m of current-season shoot & $137 \mathrm{ab}$ & $211 \mathrm{a}$ & $116 \mathrm{~b}$ \\
Total current-season shoot length $(\mathrm{cm})^{\mathrm{x}}$ & $105 \mathrm{~b}$ & $119 \mathrm{~b}$ & $151 \mathrm{a}$ \\
\hline
\end{tabular}

${ }^{\mathrm{z}}$ Values are means of 75 shoots per treatment. When used as a covariate, crop density was nonsignificant $(P$ $>0.05$ ) for all variables.

${ }^{y}$ Mean separation across rows by Tukey's HSD (5\% level).

${ }^{x}$ Total current-season shoot length per 1-year-old shoot $=$ total length of current-season lateral shoots plus length of terminal shoot.

season lateral shoots (1993 growth) originating from 1-year-old shoots, but the total length of current-season lateral shoots developing below the terminal shoot was not influenced by treatment. Terminal shoots were longest on trees with headed shoots. In Nov. 1993, the diameter of 1-year-old shoots that grew in 1992 was greatest for blossom-thinned trees and smallest for control trees. Flower bud density was higher on trees with blossom- thinned shoots than on trees with headed shoots. Compared to the control trees, total length of current-season vegetative growth per 1-yearold shoot (lateral shoots plus terminal shoots) was increased $43 \%$ and $13 \%$ by heading and blossom-thinning the shoots, respectively.

Severity of shoot-heading vs. blossom removal, 1995. Number of fruit set per tree, CD before thinning, and number and weight of fruit removed by thinning were not influenced by blossom-reducing treatment (Table 3 ). Values for all four response variables decreased as the percentage of shoot length that was treated increased from $0 \%$ to $93.25 \%$. Average fruit weight of thinned fruit was highest for trees with blossoms removed. Average fruit weight of thinned fruit was affected by treatment severity, but there was no consistent relationship with the percentage of the shoot that was treated.

Number of harvested fruit per tree, yield, $\mathrm{CD}$ at harvest, and YE were not significantly affected by blossom-reducing treatment or percentage of the shoot that was treated (Table $3)$. Yield increased linearly with increasing number of fruit harvested per tree [yield $(\mathrm{kg} /$ tree $)=7.4+0.15^{*}$ fruit $/$ tree; $r^{2}=0.85, P>$ $0.001, \mathrm{n}=39]$. Average fruit weight at harvest and crop value were higher for trees with blossom-thinned shoots than for trees with headed shoots, and both response variables were not affected by treatment severity. When used as a covariate, $\mathrm{CD}$ was significant for both fruit weight and crop value; therefore, the means in Table 3 are adjusted for the covariate. When the covariate was in the model, there was a treatment severity $\times$ treatment interaction $(P=0.07)$. Fruit weight increased as

Table 3. Fruit set per tree, crop density before thinning (CDBT), fruit thinned per tree, weight of fruit thinned per tree, average fruit weight of thinned fruit (FWT), number of fruit harvested, yield, crop density at harvest (CD), yield efficiency (YE), average fruit weight at harvest (FW), and crop value (Value) for 'Cresthaven' peach trees in 1995 as influenced by treatment [blossom removal (BR) or shoot heading (SH)] at five levels of severity to eliminate blossoms on $0 \%, 50 \%, 75 \%$, $87.5 \%$, and $93.25 \%$ of each shoot. ${ }^{2}$

\begin{tabular}{|c|c|c|c|c|c|c|c|c|c|c|c|c|}
\hline \multirow[b]{2}{*}{ Treatment } & \multirow{2}{*}{$\begin{array}{c}\text { Severity } \\
(\%)\end{array}$} & \multirow{2}{*}{$\begin{array}{l}\text { Fruit set } \\
\text { (no./tree) }\end{array}$} & \multirow{2}{*}{$\begin{array}{c}\mathrm{CDBT} \\
\left(\text { fruit } / \mathrm{cm}^{2}\right)\end{array}$} & \multicolumn{2}{|c|}{ Fruit thinned } & \multirow{2}{*}{$\begin{array}{c}\text { FWT } \\
(\mathrm{g})\end{array}$} & \multicolumn{2}{|c|}{ Fruit harvested } & \multirow{2}{*}{$\begin{array}{c}\mathrm{CD} \\
\text { (fruit } / \mathrm{cm}^{2} \text { ) }\end{array}$} & \multirow{2}{*}{$\begin{array}{c}\mathrm{YE} \\
\left(\mathrm{kg} / \mathrm{cm}^{2}\right)\end{array}$} & \multirow{2}{*}{$\begin{array}{l}\text { FW } \\
(\mathrm{g})^{\mathrm{y}}\end{array}$} & \multirow{2}{*}{$\begin{array}{c}\text { Value } \\
(\$ / \text { tree })^{y}\end{array}$} \\
\hline & & & & (no./tree) & $\overline{(\mathrm{kg} / \text { tree })}$ & & (no./tree) & $\overline{(\mathrm{kg} / \text { tree })}$ & & & & \\
\hline SH & & 522 & 6.8 & 202 & 2.6 & 13 & 283 & 47.0 & 3.5 & 0.53 & 167 & 14.32 \\
\hline & 75.0 & 508 & 6.2 & 174 & 3.5 & 20 & 312 & 54.0 & 3.6 & 0.63 & 174 & 17.40 \\
\hline & 87.5 & 422 & 5.5 & 88 & 1.6 & 21 & 255 & 46.2 & 3.3 & 0.60 & 183 & 15.24 \\
\hline & 93.25 & 328 & 4.4 & 24 & 0.3 & 14 & 242 & 43.5 & 3.3 & 0.57 & 176 & 14.77 \\
\hline Severity $_{\text {linear }}$ & & 0.01 & 0.01 & 0.01 & 0.01 & 0.01 & 0.25 & 0.49 & 0.36 & 0.36 & 0.55 & 0.38 \\
\hline $\mathrm{T} \times$ Severity $_{\text {linear }}$ & & 0.27 & 0.17 & 0.12 & 0.02 & 0.56 & 0.74 & 0.54 & 0.36 & 0.36 & 0.07 & 0.58 \\
\hline
\end{tabular}

${ }^{2}$ Means are values of 20 trees per blossom-reducing treatment and eight trees per severity of blossom-reducing treatment.

${ }^{y}$ Least squares means, adjusted for $\mathrm{CD}$ at harvest.

Table 4. Fruit set per tree, fruit thinned per tree, weight of fruit thinned (kg/tree), average fruit weight of thinned fruit (FWT) (g), thinning time (min/tree), number of fruit harvested, yield ( $\mathrm{kg} /$ tree), crop density at harvest $(\mathrm{CD})$, yield efficiency (YE), average fruit weight at harvest (FW) and net profit per tree for 'Cresthaven trees in 1996 as influenced by heading all 1-year-old shoots by half during dormant pruning and adjusting the CD to five levels (target CD) during postbloom hand-thinning. Main effect means are presented because interactions were nonsignificant $(P>0.05)$ for any response variables. ${ }^{2}$

\begin{tabular}{|c|c|c|c|c|c|c|c|c|c|c|c|c|c|}
\hline \multirow[b]{2}{*}{ Treatment } & \multirow{2}{*}{$\begin{array}{c}\text { Target } \\
\mathrm{CD} \\
\text { (fruit/ } \mathrm{cm}^{2} \text { ) }\end{array}$} & \multirow[b]{2}{*}{$\begin{array}{c}\text { Set } \\
\text { (no./tree) }\end{array}$} & \multicolumn{4}{|c|}{ Fruit at thinning time } & \multicolumn{5}{|c|}{ Fruit at harvest } & \multirow[b]{2}{*}{$\begin{array}{l}\text { Value } \\
\text { (\$/tree) }\end{array}$} & \multirow[b]{2}{*}{$\begin{array}{c}\text { Net } \\
\text { (\$/tree) }\end{array}$} \\
\hline & & & $\begin{array}{l}\text { Thinned } \\
\text { (no./tree) }\end{array}$ & $\begin{array}{c}\mathrm{Wt} \\
(\mathrm{kg} / \text { tree })\end{array}$ & $\begin{array}{c}\text { FWT } \\
(\mathrm{g})\end{array}$ & $\begin{array}{c}\text { Time } \\
(\mathrm{min} / \text { tree })\end{array}$ & No./tree & $\begin{array}{c}\text { Yield } \\
\text { (kg/tree) }\end{array}$ & $\begin{array}{l}\text { FW } \\
(\mathrm{g})\end{array}$ & $\begin{array}{c}\mathrm{CD} \\
\text { (fruit } / \mathrm{cm}^{2} \text { ) }\end{array}$ & $\begin{array}{c}\mathrm{YE} \\
\left(\mathrm{kg} \cdot \mathrm{cm}^{-2}\right)\end{array}$ & & \\
\hline Control & & 792 & 495 & 9.0 & 18.2 & 29.1 & 296 & 67.7 & 229 & 2.6 & 0.60 & 7.3 & 43.9 \\
\hline & 4 & 393 & 214 & 4.0 & 18.6 & 9.1 & 178 & 41.3 & 233 & 2.3 & 0.54 & 29.7 & 28.5 \\
\hline & 5 & 624 & 320 & 7.0 & 20.4 & 19.5 & 288 & 63.8 & 222 & 2.3 & 0.52 & 44.8 & 42.4 \\
\hline & 6 & 748 & 452 & 9.0 & 19.0 & 29.5 & 296 & 68.0 & 230 & 2.9 & 0.66 & 46.9 & 43.3 \\
\hline & 7 & 561 & 302 & 6.0 & 19.5 & 17.9 & 264 & 60.1 & 228 & 2.3 & 0.51 & 43.0 & 40.7 \\
\hline \multicolumn{2}{|c|}{ Treatment $(\mathrm{T})$} & 0.005 & 0.004 & 0.001 & 0.631 & 0.001 & 0.417 & 0.346 & 0.992 & 0.505 & 0.470 & 0.352 & 0.561 \\
\hline \multicolumn{2}{|c|}{$\mathrm{CD}$} & 0.008 & 0.100 & 0.006 & 0.674 & 0.009 & 0.001 & 0.001 & 0.317 & 0.061 & 0.036 & 0.001 & 0.003 \\
\hline \multirow{2}{*}{\multicolumn{2}{|c|}{$\mathrm{CD}_{\text {linear }}$}} & 0.003 & 0.036 & 0.008 & 0.754 & 0.006 & 0.001 & 0.001 & 0.967 & 0.098 & 0.087 & 0.001 & 0.001 \\
\hline & & 0.940 & 0.962 & 0.633 & 0.318 & 0.366 & 0.842 & 0.735 & 0.313 & 0.596 & 0.526 & 0.849 & 0.763 \\
\hline \multicolumn{2}{|l|}{$\begin{array}{l}\mathrm{CD}_{\text {Quad }} \\
\mathrm{T} \times \mathrm{CD}\end{array}$} & 0.435 & 0.475 & 0.224 & 0.862 & 0.189 & 0.799 & 0.750 & 0.628 & 0.972 & 0.956 & 0.796 & 0.746 \\
\hline
\end{tabular}

${ }^{2}$ Values are means of 20 trees per treatment and eight trees per $\mathrm{CD}$. The interactions for treatment $\times \mathrm{CD}_{\text {linear }}$, and treatment $\times \mathrm{CD}_{\text {Quadratic }}$ were also nonsignificant $(P=0.05)$. 
severity increased for blossom removal, but not for shoot-heading (data not shown). To evaluate net profit per tree, multiple regression models were developed using treatment as a categorical variable, and percentage of the shoot length treated as a continuous regressor variable; models also included $\mathrm{CD}$, yield, or fruit harvested per tree as covariates. Net profit per tree increased linearly as yield and fruit harvested per tree increased, but profit was not related to $\mathrm{CD}$, treatment, or percentage of shoot length removed by heading or with blossoms removed (data not shown). Scatter plots of the raw data indicate that crop value was greatest for blossom-removed trees, but when analysis of covariance was used to adjust the means for number of fruit harvested per tree, crop value and net profit were not affected by blossom-reducing treatment method.

Shoot-heading, 1996. Fruit set, fruit thinned per tree, weight of fruit thinned per tree, and thinning time were reduced by $33 \%, 49 \%$, $54 \%$, and $52 \%$, respectively, when all 1 -yearold shoots were headed by $50 \%$ (Table 4). All four response variables increased linearly as the target $\mathrm{CD}$ (number of shoots per tree retained after dormant pruning) increased. Treatment and number of shoots per tree did not affect average fruit weight of thinned fruit. The number of fruit harvested per tree and yield was not affected by treatment, but both increased linearly as target CD increased $\left(\mathrm{r}^{2}>\right.$ $0.42, P>0.001)$. Treatment and target $\mathrm{CD}$ did not affect average fruit weight. Treatment did not affect $\mathrm{CD}$ or YE at harvest, but YE increased linearly with increasing target $\mathrm{CD}$. Treatment did not affect crop value and net profit, but both response variables increased linearly with increasing target $\mathrm{CD}\left(\mathrm{r}^{2}>0.40, P\right.$ $>0.001)$

\section{Discussion}

Average fruit weight generally is negatively related to number of fruit per tree (Johnson and Handley, 1989) and the desired number of fruit per tree is usually obtained by hand-thinning within 50 DAFB. Evaluating treatments in this study was difficult because treatments often influenced crop load. Although attempts were made to adjust $\mathrm{CD}$ with postbloom hand-thinning, $\mathrm{CD}$ at harvest time often was lower than desired. Failure to obtain the target CD probably resulted from difficulty in counting small fruit on the tree. Originally, CD was intended to be a quantitative treatment that could be evaluated with orthogonal polynomials. But because $\mathrm{CD}$ was actually a continuous variable, it was included in the models as a covariate.

Different trees within the same uniform block of 'Cresthaven' were used for all experiments, but response to blossom-removal and shoot-heading varied with year, probably because initial number of fruit set per tree varied from 480 to 1990,200 to 1220 , and 240 to 1600 in 1993, 1995, and 1996, respectively. Therefore, comparing results from different years is difficult. When the same percentage of shoot length was treated, blossom removal and shoot-heading generally influenced fruit set, number of fruit thinned per tree, and fruit harvested per tree similarly. Eliminating blossoms from the terminal half of fruiting shoots reduced fruit set, but the magnitude of the reduction varied with the season. Compared to nontreated control trees, eliminating blossoms from the terminal half of each shoot reduced fruit set an average of $16 \%, 15 \%$, and $27 \%$ in 1993, 1995, and 1996, respectively. These variable results are not surprising because flower bud density on the basal portion of a shoot can be influenced by the previous season's crop load (Byers et al., 1990). Additionally, flower bud density and the proportion of flowers that set fruit can vary $>2$-fold depending on the year (Marini, 1985a). Fruit set was not proportional to the percentage of shoot length with blossoms retained because flower bud density is greater at the basal half of the shoot due to shorter internode length and more flower buds per node (Byers et al., 1990; Coston, 1983). Treatments had a greater influence on the number of fruit per tree removed by hand-thinning than on fruit set per tree. Compared to control trees, removing blossoms from the terminal half of the shoot, by heading or hand-removal, reduced the number of fruit thinned per tree by $20 \%, 33 \%$, and $43 \%$ in 1993, 1995, and 1996, respectively. Therefore, eliminating bloom from the terminal half of shoots reduced the amount of postbloom hand fruit thinning required to adjust the crop load to desired levels by twice as much as it reduced fruit set. The apparent discrepancy between number of fruit set and number of fruit removed by thinning probably was due to greater fruit-setting potential of flowers on the terminal half of the shoot (Byers et al., 1990).

Average fruit weight of fruit removed at thinning was influenced by treatments in 1993 and 1995, but not in 1996 when the treatments were less extreme. Apparently, relatively heavy fruit set is required to retard early-season fruit growth. Usually there is a negative linear relationship between number of fruit harvested per tree and average fruit weight (Johnson and Handley, 1989). However, results from this study indicate that this relationship can be altered by treatments that affect fruit set. Average fruit weight was greater for trees with blossom removal than for trees with headed shoots in 1995, but not in 1993. In 1995, average fruit weight at harvest increased linearly as blossom-removal severity increased, but fruit weight declined with increasing severity of heading shoots (data not shown). Average fruit weight at harvest for trees with headed shoots may have been negatively effected by low assimilate levels per tree caused by inadequate leaf surface to support earlyseason fruit growth. Heading dormant shoots appeared to delay the development of shoots $\approx 14$ to $20 \mathrm{~d}$. Average fruit weight generally was negatively related to the number of fruit set per tree and the number of fruit harvested per tree, but the fruit set reduction by blossomremoval or shoot-heading in this study may have been too little to improve fruit weight.

In general, net crop value was positively related to the number of fruit harvested per tree but was usually not influenced by treatment.
Results from these experiments indicate that preventing cropping on the terminal half of all shoots on a tree by heading or blossom-removal can reduce fruit set compared to nontreated control trees without reducing average fruit weight at harvest. However, these treatments may not improve net profit unless initial fruit set is $>2100$ fruit per tree. Blossom-removal usually improved average fruit weight more than shoot-heading, but shootheading required less time than manual blossom removal. In 1993, when averaged over all three levels of $\mathrm{CD}$, blossom-removal took $15.3 \mathrm{~min} /$ tree, whereas shoot-heading took 4.9 $\mathrm{min} /$ tree. Both treatments reduced subsequent hand-thinning time by $20 \%$ to $40 \%$.

In the present study, tree-to-tree variation for yield, CD, and average fruit weight was high and similar results have been previously reported for peach (Marini, 1985b; Schultz and Schneider, 1955). Inability to accurately adjust the crop load by hand-thinning to specific CDs or number of fruit per tree was frustrating. Often the number of fruit per tree recorded at thinning time was not similar to the number of fruit harvested per tree. The $\mathrm{CD}$ and number of fruit harvested per tree in this study were less highly correlated than expected $\left(r^{2}=\right.$ 0.63 to 0.77 ). Average fruit weight at harvest may differ for trees with similar numbers of fruit per tree, but with different CDs. Plots of data from this study indicate that for trees with similar numbers of fruit harvested per tree, the trees with large trunks had low CDs and also had the highest average fruit weight (data not shown). Thus, average fruit weight appears to be influenced by TCSA as well as by the number of fruit harvested per tree. Additional experiments, specifically designed to evaluate the individual or interrelated influences of these two variables on average fruit weight, are needed. To minimize variation in future experiments, trees with similar TCSAs should be used for treatments. Blocking on the basis of TCSA, followed by thinning to a certain number of fruit per tree, may also reduce residual error

Counting fruit on the tree 40 to 50 DAFB was not a satisfactory method of adjusting crop load because $\mathrm{CD}$ at harvest was often $25 \%$ lower or higher than desired. Peach researchers might consider pruning to remove all but a certain number of 1-year-old shoots per tree, followed by thinning to remove all but a certain number of fruit per shoot. This method of adjusting crop load was relatively fast and reduced the tree-to-tree variation in number of fruit per tree.

\section{Literature Cited}

Baugher, T.A., K.C. Elliott, S.H. Blizzard, S.I. Walter, T.A. Keiser. 1988. Mechanical bloom thinning of peach. HortScience 23:981-983.

Byers, R.E., D.H. Carbaugh, and C.N. Presley. 1990. The influence of bloom thinning and $\mathrm{GA}_{3}$ sprays on flower bud numbers and distribution in peach trees. J. Hort. Sci. 65:143-150.

Byers, R.E. and C.G. Lyons, Jr. 1985. Peach flower thinning and possible sites of action of desiccating chemicals. J. Amer. Soc. Hort. Sci. 110:662667 
Coston, D.C. 1983. Peach tree physiology. In: M.E. Ferree and P.F. Bertrand (eds.). Peach growers handbook. Georgia Coop. Ext. Serv. Hdbk. No. 1 , Athens.

Havis, A.L. 1962. Effect of time of fruit thinning of 'Redhaven' peach. Proc. Amer. Soc. Hort. Sci. 80:172-176.

Johnson, R.S. and D.F. Handley. 1989. Thinning response of early, mid-, and late-season peaches. J. Amer. Soc. Hort. Sci. 114:852-855.

Littell, R.C., R.J. Freund, and P.C. Spector. 1992. SAS system for linear models. SAS Inst., Cary,
N.C.

Marini, R.P. 1985a. Vegetative growth, yield, and fruit quality of peach as influenced by dormant pruning, summer pruning, and summer topping. J. Amer. Soc. Hort. Sci. 110:133-139.

Marini, R.P. 1985b. Sample size estimates for peach tree growth and yield experiments. J. Amer. Soc. Hort. Sci. 110:604-608.

Marini, R.P. 1988. Pruning peach trees. Virginia Coop. Ext. Publ. 422-020.

Overholser, E.L. and L.L. Claypool. 1931. The relation of leaf area per peach to physical prop- erties and chemical composition. Proc. Amer. Soc. Hort. Sci. 28:15-17.

Schultz, E.F. and G.W. Schneider. 1955. Sample size necessary to estimate size and quality of fruit, growth of trees, and percent fruit set of apples and peaches. Proc. Amer. Soc. Hort. Sci. 66:36-44.

Weinberger, J.H. and F.P. Cullinan. 1932. Further studies on the relation between leaf area and size of fruit, chemical composition, and fruit bud formation in Elberta peach. Proc. Amer. Soc. Hort. Sci. 29:23-27. 